\title{
Pulsed-field gel electrophoresis analysis of the genome of amino acid producing corynebacteria: chromosome sizes and diversity of restriction patterns
}

\author{
Antonio Correia, Juan F. Martín and Jose M. Castro
}

Author for correspondence: Juan F. Martín. Tel: +34 87 291505. Fax: +34 87291506.

Section of Microbiology, Department of Ecology, Genetics and Microbiology, Faculty of Biology, University of León, 24071 León, Spain

\begin{abstract}
A large number of species of corynebacteria are known to be amino acid producers, including members of the genera Corynebacterium and Brevibacterium. Pulsed-field gel electrophoresis (PFGE) of DNA fragments obtained by using endonucleases which recognize AT-rich hexanucleotide or octanucleotide sequences produces a discrete pattern of bands useful for fingerprinting and physical mapping of the chromosome. Using Pacl and Swal endonucleases the genome of Brevibacterium lactofermentum ATCC 13869 (genome size $3052 \mathrm{~kb}$ ) was consistently cut into 26 and 20 bands, respectively, and the genome of Corynebacterium glutamicum ATCC 13032 (2987 kb) yielded 27 and 26 fragments, respectively. The pattern of restriction fragments was identical for related strains (B. lactofermentum ATCC 13869, B. lactofermentum BLO, B. lactofermentum R31) but different from the pattern of fragments of other soil isolates of the same species (B. lactofermentum DSM 20412) or from closely related organisms such as $C$. glutamicum ; the different pattern of restriction fragments may be used to differentiate taxonomically related species. Brevibacterium linens showed a different behaviour, due to its high G + C content; its genome ( $3105 \mathrm{~kb})$ was resolved into 8 or 15 fragments, respectively, by digestion with the hexanucleotide-recognizing endonucleases Dral and Asel. PFGE of DNA fragments obtained using these enzymes is a powerful technique for quick resolution of the corynebacteria genome into a small number of large fragments.
\end{abstract}

Keywords: Corynebacterium, Brevibacterium, PFGE

\section{INTRODUCTION}

Corynebacteria are pleomorphic, non-spore forming, Gram-positive bacteria (Jones \& Collins, 1986). The group includes diverse taxa, some of which are plant or animal pathogens, and others, saprophytes. Among the non-pathogens there are strains of industrial relevance as amino acid producers, classified as members of the genera Corynebacterium and Brevibacterium.

Several closely related species are commonly referred to as 'glutamic-acid bacteria', including Corynebacterium glutamicum and Brevibacterium lactofermentum. The two species share many common characteristics, such as cellular fatty acid composition, the presence of mycolic acids and peptidoglycans containing meso-diaminopimelate in the

Abbreviation: PFGE, pulsed-field gel electrophoresis. cell wall (Suzuki \& Komagata, 1983), similar nucleotide sequence of genes encoding the same enzymes in both species, $G+C$ content in the range 54-56\% (typical of true members of the genus Corynebacterium) and a high degree of similarity by DNA-DNA hybridization studies. Based on these data, the transfer of $B$. lactofermentum to the genus Corynebacterium has been proposed (Liebl et al., 1991). Differentiation of strains classified as C. glutamicum and $B$. lactofermentum has been made by analysis of rDNA restriction patterns (Liebl $e$ t al., 1991) and by restriction fragment length polymorphisms around bom genes (Eikmanns et al., 1991). Brevibacterium linens, the type species of genus Brevibacterium (usually isolated from cheese sources), has a higher $\mathrm{G}+\mathrm{C}$ content than $B$. lactofermentum and C. glutamicum. One strain, B. linens ATCC 19391, is a patented L-lysine producer. This strain belongs to the DNA homology group of the type species, $B$. linens A TCC 9172 (Fiedler et al., 1981). 
Considerable progress has been made on the molecular genetics of amino-acid-producing corynebacteria, especially in relation to cloning vectors, transformation systems and the study of structure, expression and regulation of genes involved in amino acid biosynthetic pathways (Martín et al., 1987; Martín, 1989), but little is known about their global genome organization.

Pulsed-field gel electrophoresis (PFGE) is a powerful technique for studying the size and organization of bacterial genomes. Physical maps can be generated in the absence of detailed genetic maps. Identification of species, or strains classified in the same species, has been attempted with the use of rare-cutting restriction endonucleases followed by separation of the fragments of PFGE. The procedure has been applied successfully to Pseudomonas species (Grothues \& Tümmler, 1991), Streptomyces ambofaciens strains (Leblond et al., 1990), Rhizobiaceae (Sobral et al., 1991), Lactococcus (Tanskanen et al., 1990) and Staphylococcus aureus strains (El-Adhami et al., 1991).

In this paper we report the determination of chromosome sizes of strains classified as B. lactofermentum, C. glutamicum and $B$. linens by addition of the sizes of fragments obtained by digestion with two different enzymes that cut the genome infrequently. We also describe conditions for electrophoretic separation of large restriction fragments that allow comparison of strains on a single gel run. To our knowledge this is the first study of the restriction patterns and genome sizes of corynebacteria using PFGE.
Table 1. Strains used in this study and their corresponding $\mathrm{G}+\mathrm{C}$ content

Data taken from Liebl et al. (1991).

\begin{tabular}{|c|c|c|}
\hline \multicolumn{2}{|c|}{ Bacterial strains } & $\% \mathbf{G}+\mathbf{C}$ \\
\hline B. lactofermentum & ATCC 13869 & $54 \cdot 3$ \\
\hline B. lactofermentum & $\begin{array}{l}\text { BLO (non-pigmented } \\
\text { mutant) } \\
\text { R31 (restriction-deficient } \\
\text { mutant) } \\
\text { ATCC } 13869 \text { derivatives }\end{array}$ & \\
\hline B. lactofermentum & DSM 20412 & $54 \cdot 8$ \\
\hline C. glutamicum & ATCC 13032 & $54 \cdot 6$ \\
\hline B. linens & A'TCC 19391 & $63 \cdot 8$ \\
\hline
\end{tabular}

\section{METHODS}

Bacterial strains. Bacterial strains used in this study and their corresponding $\mathrm{G}+\mathrm{C}$ content are listed in Table 1 .

Preparation and digestion of high molecular mass DNA. Bacteria were grown to an $\mathrm{OD}_{600}$ of 0.8-1.0 in Trypticase Soy Broth containing $0.5 \%$ glucose and $1 \%(\mathrm{w} / \mathrm{v})$ glycine. Cells were harvested, washed and resuspended in TE buffer $(10 \mathrm{mM}$ Tris/HCl, $1 \mathrm{mM}$ EDTA, $\mathrm{pH} 8 \cdot 0$ ) and then mixed with 1 vol. $1 \%(\mathrm{w} / \mathrm{v})$ low-gelling agarose at $42{ }^{\circ} \mathrm{C}$. The mixture was allowed to solidify in $100 \mu \mathrm{l}$ plastic moulds to form blocks that were subsequently treated for $24 \mathrm{~h}$ at $37^{\circ} \mathrm{C}$ with lysis solution (a)

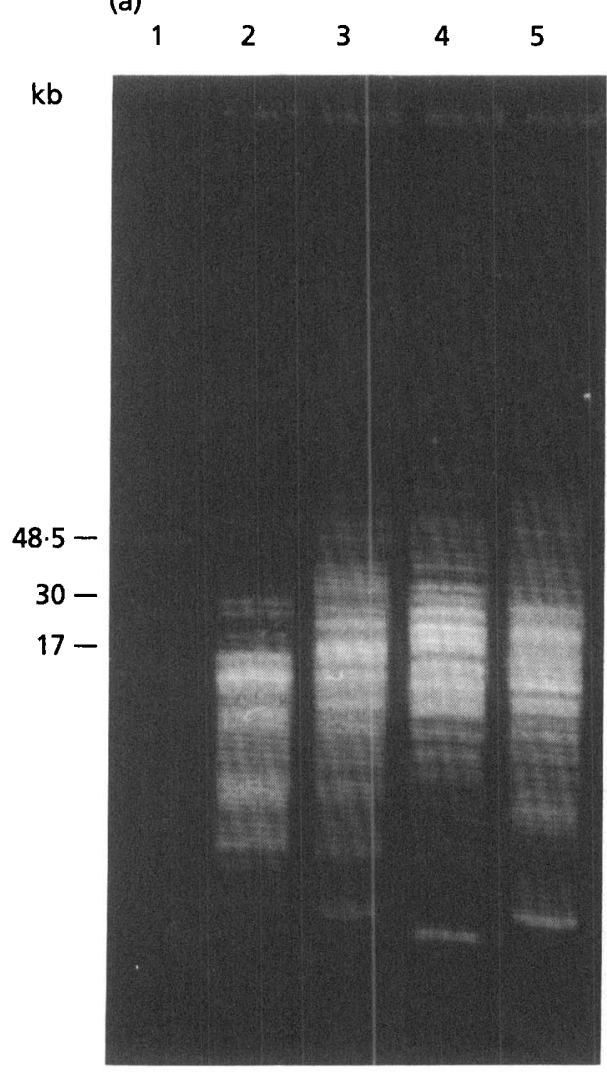

(b)

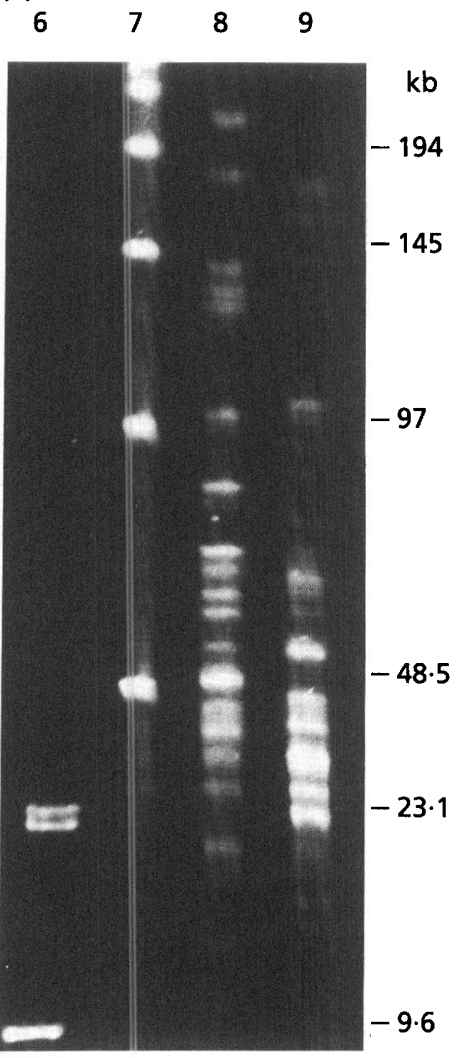

Fig. 1. Restriction pattern of total DNA of $B$. lactofermentum ATCC 13869 with enzymes recognizing 6 bp AT-rich sequences (a) or 8 bp GC-rich sequences (b). (a) Lanes: 1 , lambda partially digested with Kpnl; 2, Dral digestion; 3, Spel digestion; 4, Sspl digestion; 5, Xbal digestion. Separations were carried out in the LKB Pulsaphor at $170 \mathrm{~V}$ using pulses of $2.5,5$ and $7.5 \mathrm{~s}$ for $8 \mathrm{~h}$ each. (b) Lanes: 6, HindIII-digested lambda DNA; 7, lambda ladder; 8, Notl digestion; 9 , Sfil digestion. Fragments were separated in the LKB Pulsaphor at $170 \mathrm{~V}$ using pulses of $6 \mathrm{~s}$ for $18 \mathrm{~h}, 12 \mathrm{~s}$ for $18 \mathrm{~h}$ and $25 \mathrm{~s}$ for $8 \mathrm{~h}$. Sizes in $k b$ are indicated on the left and right. Note that the enzymes recognizing 6 bp AT-rich sequences resulted in too many fragments of small size (a) whereas good resolution was obtained with enzymes that recognize 8 bp GC-rich sequences (b). 
Table 2. Restriction fragments and sizes of the chromosomes of $B$. lactofermentum, $C$. glutamicum and $B$. linens strains

These estimates were based on the measurement of fragments generated from a number of PFGE experiments conducted utilizing various pulse times.

\begin{tabular}{|c|c|c|c|c|c|c|c|c|}
\hline \multirow[t]{2}{*}{ Band } & \multicolumn{2}{|c|}{$\begin{array}{l}\text { B. lactofermentum } \\
\text { ATCC } 13869\end{array}$} & \multicolumn{2}{|c|}{$\begin{array}{l}\text { B. lactofermentum } \\
\text { DSM } 20412\end{array}$} & \multicolumn{2}{|c|}{$\begin{array}{l}\text { C. glutamicum } \\
\text { ATCC } 13032\end{array}$} & \multicolumn{2}{|c|}{$\begin{array}{c}\text { B. linens } \\
\text { ATCC } 19391\end{array}$} \\
\hline & PacI & SwaI & PacI & SwaI & PacI & SwaI & DraI & AseI \\
\hline A & 390 & 557 & 606 & 557 & 518 & 325 & 874 & 720 \\
\hline B & 300 & 342 & 264 & 315 & 385 & 276 & 610 & 600 \\
\hline C & 264 & 340 & 220 & 295 & 266 & 262 & 567 & 390 \\
\hline $\mathrm{D}$ & 242 & 262 & 210 & 244 & 264 & 242 & 348 & 285 \\
\hline $\mathrm{E}$ & 212 & 242 & 205 & 215 & 212 & 237 & 325 & 240 \\
\hline$F$ & 180 & 222 & 180 & 188 & 164 & 199 & 150 & 190 \\
\hline G & $175^{*}$ & 215 & 164 & 176 & 157 & 179 & 115 & 170 \\
\hline $\mathrm{H}$ & 168 & 154 & 162 & 160 & 138 & 168 & 76 & 115 \\
\hline I & 148 & 128 & 150 & 146 & $135^{*}$ & 165 & & 110 \\
\hline $\mathrm{J}$ & 135 & 120 & 146 & 123 & 98 & 126 & & 75 \\
\hline $\mathrm{K}$ & 98 & 106 & 144 & 122 & 97 & 118 & & $65^{*}$ \\
\hline $\mathrm{L}$ & 94 & 70 & 108 & 116 & 84 & 110 & & 45 \\
\hline M & 84 & 51 & 100 & 78 & 62 & 90 & & 20 \\
\hline $\mathrm{N}$ & 62 & $50^{*}$ & 92 & 70 & 50 & 74 & & 15 \\
\hline $\mathrm{O}$ & 50 & 48 & 84 & 68 & $46^{*}$ & 70 & & \\
\hline $\mathrm{P}$ & 48 & 35 & 62 & 51 & 25 & 68 & & \\
\hline $\mathrm{Q}$ & $46^{*}$ & $21 *$ & 35 & 45 & 23 & 51 & & \\
\hline $\mathrm{R}$ & 37 & 18 & 28 & 35 & 18 & 45 & & \\
\hline$S$ & 28 & & 27 & 34 & 14 & 38 & & \\
\hline $\mathrm{T}$ & 13 & & 23 & 21 & 13 & 30 & & \\
\hline $\mathrm{U}$ & 11 & & 14 & 11 & 9 & 21 & & \\
\hline V & 8 & & 13 & & 8 & 18 & & \\
\hline W & 7 & & 7 & & $7^{*}$ & 15 & & \\
\hline $\mathrm{X}$ & 5 & & & & 6 & $13^{*}$ & & \\
\hline Y & & & & & & 5 & & \\
\hline $\begin{array}{l}\text { Genome } \\
\text { size }(\mathbf{k b})\end{array}$ & 3026 & 3052 & 3044 & 3070 & 2987 & 2958 & 3065 & 3105 \\
\hline
\end{tabular}

* Indicates doublets.

[1 $\mathrm{M} \mathrm{NaCl}, 10 \mathrm{mM}$ Tris $/ \mathrm{HCl}, 0 \cdot 5 \%$ Sarkosyl, $0 \cdot 2 \%$ sodium deoxycholate, $0 \cdot 25 \mathrm{M}$ EDTA and $1 \mathrm{mg}$ lysozyme (Boehringer Mannheim) $\mathrm{ml}^{-1}$ ], followed by a $24 \mathrm{~h}$ treatment at $50{ }^{\circ} \mathrm{C}$ with $1 \mu \mathrm{g}$ proteinase $\mathrm{K}$ (Sigma) $\mathrm{ml}^{-1}$ in $0.25 \mathrm{M}$ EDTA, $1 \%$ Sarkosyl. Blocks were kept at $4{ }^{\circ} \mathrm{C}$ in the last solution without proteinase $\mathrm{K}$.

For digestion with restriction endonucleases blocks were cut into pieces containing approximately $1 \mu \mathrm{g}$ DNA and were washed for $1 \mathrm{~h}$ at room temperature in $1 \mathrm{ml}$ TE with $1 \mathrm{mM}$ PMSF added, followed by a $1 \mathrm{~h}$ wash in $10 \mathrm{mM}$ Tris/ $\mathrm{HCl}$, and then equilibrated in the appropriate restriction buffer for $1 \mathrm{~h}$. The digestions were carried out in a final volume of $100 \mu \mathrm{l}$ in the presence of 10-20 units of enzyme. Restriction enzymes were purchased either from New England BioLabs or from Boehringer Mannheim.

PFGE. Separation of macrofragments of DNA was carried out either in a Pulsaphor apparatus (LKB) equipped with a hexagonal electrode array or in a Bio-Rad CHEF-DR II apparatus (Bio-Rad). Agarose gels were prepared at $1-1 \cdot 2 \%$ concentration in $0.5 \times$ TBE buffer $(1 \times$ TBE buffer: $90 \mathrm{mM}$
Tris $/ \mathrm{HCl}, 90 \mathrm{mM}$ boric acid, $2 \cdot 5 \mathrm{mM} \mathrm{Na}{ }_{2}$ EDTA, pH 8.2). Separation of fragments was done at $6 \mathrm{~V} \mathrm{~cm}^{-1}$, at $8{ }^{\circ} \mathrm{C}$, with pulse times varying with the size range. Chromosomes of Saccharomyces cerevisiae (Bio-Rad) and concatemers of lambda DNA were used as molecular size standards. The measurements were made on the negatives and then confirmed with measurements obtained from scanning densitometry and image analysis (BioImage, Millipore).

\section{RESULTS}

\section{Selection of restriction endonucleases to obtain large DNA fragments}

Due to the high $\mathrm{G}+\mathrm{C}$ content of corynebacteria (Table 1) and taking into account the tri- and tetranucleotide frequencies obtained by analysis of corynebacterial DNA sequences deposited in GenBank (Malumbres et al., 1993), we tested enzymes expected to recognize only a few sites in these genomes. These enzymes recognized (i) 6 bp AT- 
(a)

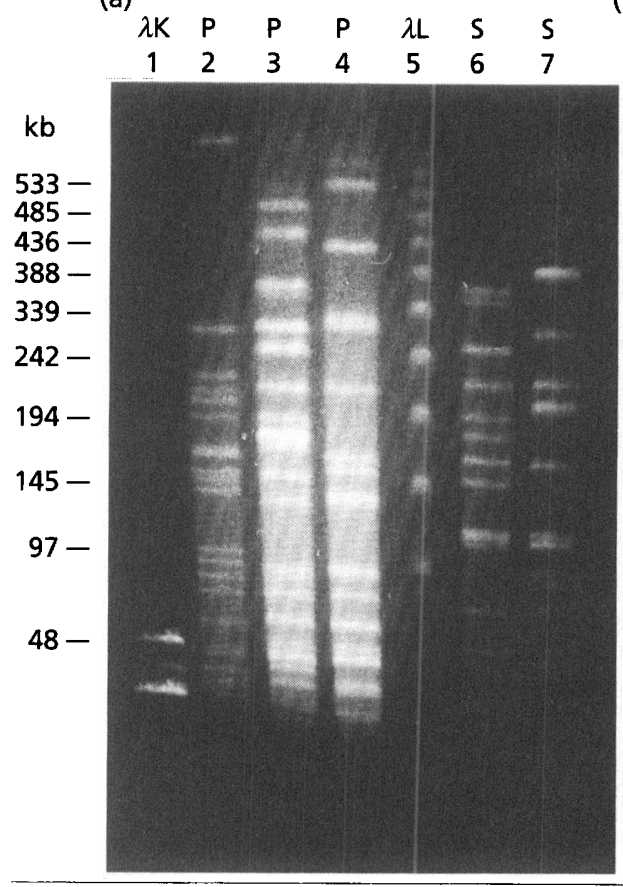

(b)

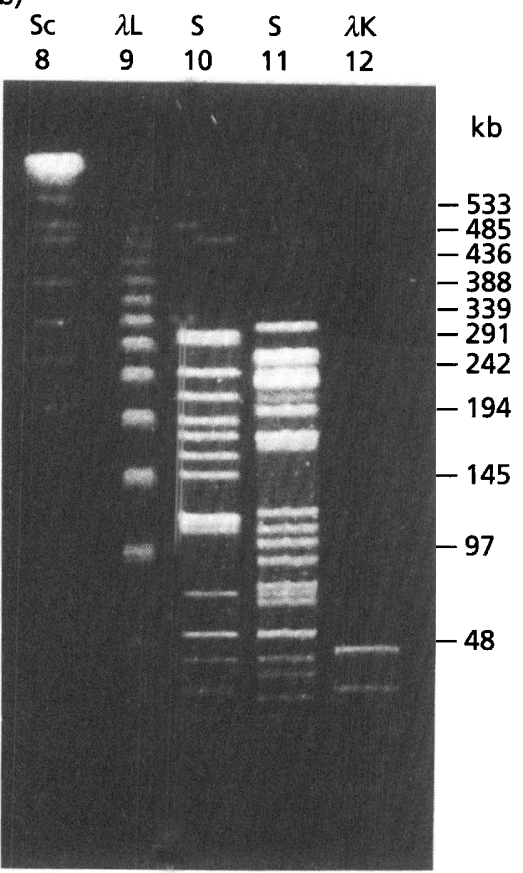

Fig. 2. Comparison of the restriction pattern of B. lactofermentum strains ATCC 13869 and DSM 20412 and C. glutamicum ATCC 13032 after digestion with PaCl or Swal. Separations were carried out in the Bio-Rad CHEF at $200 \mathrm{~V}$ using increasing time pulses of $5-20 \mathrm{~s}$ for $16 \mathrm{~h}$ and then $20-70 \mathrm{~s}$ for $20 \mathrm{~h}$ (a) or $16 \mathrm{~h}$ (b). Lanes: 2, 6 and 10, DSM 20412; 3 and 7, ATCC 13869; 4 and 11, ATCC 13032. P, Pacl; S, Swal; $\lambda$ K, lambda Kpnl; $\lambda \mathrm{L}$, lambda ladder; SC, $S$. cerevisiae chromosomes. rich, or CTAG-containing sequences such as DraI (TTTAAA), AseI (ATTAAT), $S s p I$ (AATATT), XbaI (TCTAGA) and $S$ peI (ACTAGT) or (ii) 8 bp GC-rich or AT-rich recognition sequences such as SfiI (GGCCNGGCC where N stands for any of the four nucleotides), NotI (GCGGCCGC), PacI (TTAATTAA) and SwaI (ATTTAAAT).

In a first approach we digested the chromosome of $B$. lactofermentum with the enzymes referred to above. Endonucleases which recognized hexanucleotides were found to be of little interest for analysing the genomes of the typical glutamic acid bacteria, $B$. lactofermentum and $C$. glutamicum. As in most bacterial genomes, the sequence ${ }^{5} \mathrm{CTAG}^{3^{\prime}}$ is the rarest tetranucleotide present in the genome of corynebacteria, among those recognized by commercially available endonucleases, representing less than $0.02 \%$ of the total possible tetranucleotide combinations found in 43215 bp examined. Enzymes recognizing CTAG-containing sequences digested the chromosomal DNA in too many fragments to allow accurate resolution, with the largest being about $50 \mathrm{~kb}$. Similar results were observed when enzymes which recognize 6 bp AT-rich sequences were used, despite the high $G+C$ content of corynebacteria (Fig. 1a).

Endonucleases which recognize 8 bp GC-rich sequences gave too many fragments to be useful in routine restriction mapping of glutamic acid corynebacteria (Fig. 1b) whereas endonucleases recognizing $8 \mathrm{bp}$ AT-rich sequences were adequate. Discrete patterns of fragments from the DNA of these bacteria were obtained with PacI and SwaI. The three strains analysed with these two enzymes showed between 20 and 27 restriction fragments, ranging from about 5 to $600 \mathrm{~kb}$ (Table 2), and with a distribution that allowed separation in a single gel run. Conventional electrophoresis and pulsed-field electro- phoresis using short time pulses were used to estimate sizes of the lower molecular mass bands (data not shown). The restriction patterns were quite distinct for each strain; on visual comparison it was possible to find only a few possible common motifs in the DNAs of all three strains of $B$. lactofermentum and $C$. glutamicum using digestions with the same enzyme (Fig. 2). We tried to resolve all the fragments resulting from digestion with NotI and SfiI (recognizing GC-rich octanucleotides) by changing pulse times in order to get different windows of resolution. Nevertheless, we concluded that the sum of the NotI and SfiI restriction fragments of the chromosome of B. lactofermentum ATCC 13869 identified by this procedure was always smaller than the values obtained by summing the PacI or SwaI fragments, most probably due to the presence of several doublets or triplets that could not be resolved.

Restriction endonucleases which recognize $6 \mathrm{bp}$ sequences proved to be useful for the analysis of the genome of $B$. linens. All the enzymes gave patterns that could be resolved by PFGE; AseI (not shown in the figure) and in particular DraI gave the smallest number of fragments (Fig. 3 and Table 2).

\section{Genome sizes}

A consistent pattern of restriction fragments was routinely obtained in experiments using either PacI or SwaI for cutting the DNA of either $B$. lactofermentum or $C$. glutamicum. Therefore, it was possible to establish the size of the genome by adding the size of different fragments. Similarly, using either DraI or $A s e \mathrm{I}$, it was possible to determine accurately the chromosome size of $B$. linens ATCC 19391.

The genome sizes were estimated to be $3052 \mathrm{~kb}$ for $B$. 
(a)

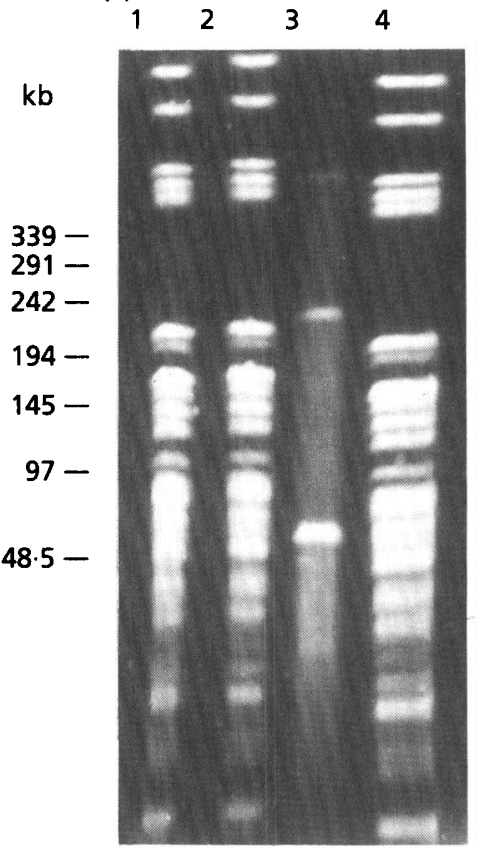

(b)

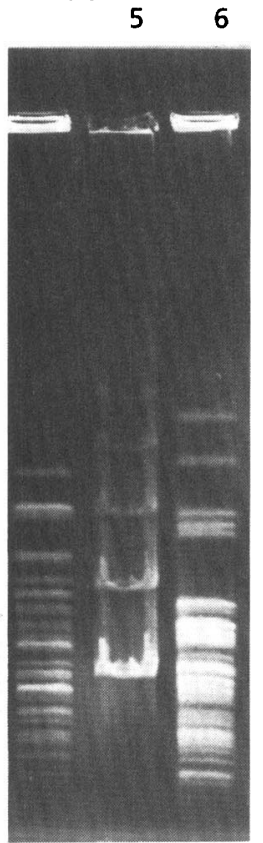

$\mathrm{kb}$

-727
-678
-630
-581
-533
-485
-436
-388

$-339$

$-291$

$-242$

$-194$

$-145$

$-97$

$-48 \cdot 5$

Fig. 3. Resolution of the genome of $B$. linens with enzymes recognizing 6 bp AT-rich sequences. (a) Lanes: 1, lambda ladder; 2, Spel digestion; 3, Sspl digestion; 4, Xbal digestion. Fragments were separated in the LKB Pulsaphor at $170 \mathrm{~V}$ using pulses of 5, 10 and $15 \mathrm{~s}$ for $8 \mathrm{~h}$ each. (b) Lanes: 5, resolution into eight fragments (A-H) after digestion with Dral; 6, lambda ladder. Fragments were separated in the Bio-Rad CHEF at $200 \mathrm{~V}$ using ramped pulses from $10-30 \mathrm{~s}$ for $16 \mathrm{~h}$ and $40-80 \mathrm{~s}$ for $18 \mathrm{~h}$. Note that except for Dral, the enzymes used resulted in too many fragments of small size to be accurately resolved. Sizes of the largest Dral fragments were calculated by comparison of their migration with that of $S$. cerevisiae chromosomes (not shown in the figure).

lactofermentum ATCC $13869,3070 \mathrm{~kb}$ for B. lactofermentum DSM 20412, $2987 \mathrm{~kb}$ for C. glutamicum ATCC 13032 and 3105 for B. linens ATCC 19391 (Table 2).

\section{Closely related strains show the same pattern of restriction fragments}

It was of interest to study whether closely related strains showed differences in the restriction pattern. As shown in Fig. 4, strains $B$. lactofermentum $\mathrm{BLO}$, a non-pigmented mutant, and B. lactofermentum R31 (an easily transformable strain which does not restrict exogenous DNA; L. M. Mateos, M. Malumbres and J. F. Martín, unpublished) which derived from ATCC 13869, showed the same restriction pattern as the parental $B$. lactofermentum strain. However B. lactofermentum ATCC 13869 and DSM 20412 showed some clearly different bands. Both of these soil isolates were initially classified as B. lactofermentum, although it has been suggested that strain DSM 20412 should be reclassified as C. glutamicum (Liebl et al., 1991). These results indicate that separation of restriction fragments by PFGE can be used to identify derivatives obtained from a parental strain and to distinguish them from different soil isolates of the same species.

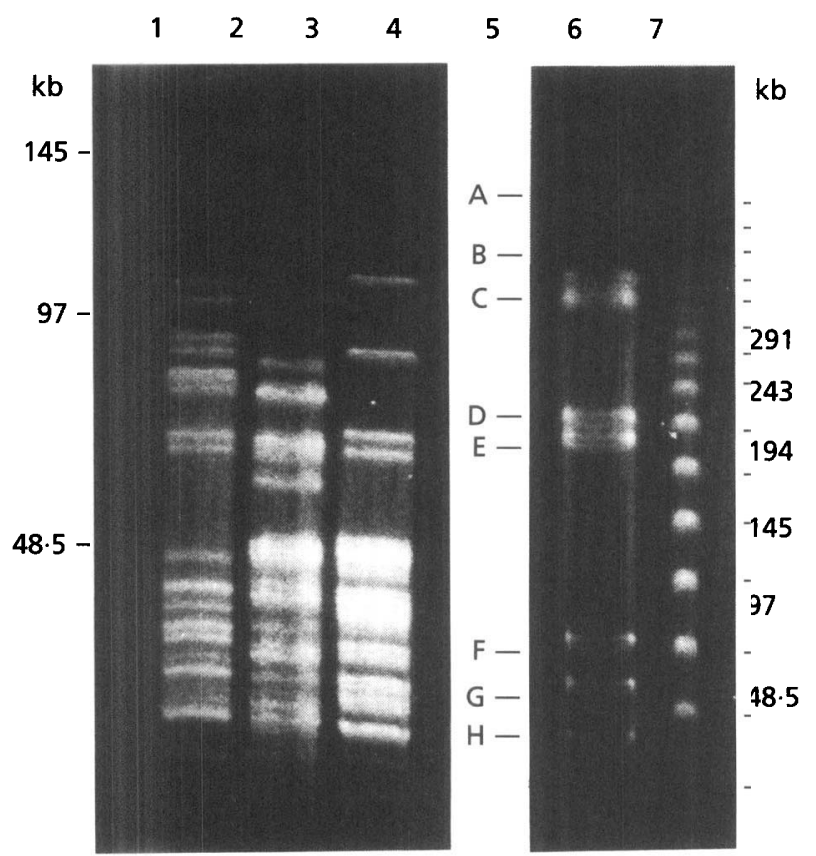

Fig. 4. Use of PFGE for identification of different strains of $B$. lactofermentum and discrimination of C. glutamicum. Total DNAs were digested with Not1. Lanes: $1, B$. lactofermentum ATCC $13869 ; 2$, B. lactofermentum BL0; 3, lambda ladder; 4, B. lactofermentum R31; 5, C. glutamicum ATCC 13032; 6, lambda ladder; 7, B. lactofermentum ATCC 13869. Both separations were carried out in the Bio-Rad-CHEF apparatus at $180 \mathrm{~V}$ using pulse times of $20 \mathrm{~s}$ for $8 \mathrm{~h}, 15 \mathrm{~s}$ for $16 \mathrm{~h}, 5 \mathrm{~s}$ for $12 \mathrm{~h}$ and $2.5 \mathrm{~s}$ for $8 \mathrm{~h}$ (left), and a pulse gradient from 2 to $40 \mathrm{~s}$ for $24 \mathrm{~h}$ (right).

\section{DISCUSSION}

The restriction patterns and genome sizes of three different corynebacterial species have been established by resolution of large DNA fragments using PFGE. Pulse conditions were adjusted so that all the restriction fragments could be resolved, as shown by the almost identical values of genome size obtained with two different enzymes. The chromosome of these bacteria is smaller than that of Escherichia coli $(4700 \mathrm{~kb})$ (Smith et al., 1987) but it is similar to, or even larger than, the genome of related Gram-positive unicellular bacteria such as Lactococcus lactis (2500 kb), Stapbylococcus aureus $(2860 \mathrm{~kb})$, Streptococcus thermophilus (1700 kb) (Bourgeois et al., 1989; Jones \& Collins, 1986; Krawiec \& Riley, 1990), and Leuconostoc oenos (1100-1500 kb) (Daniel et al., 1993). The genome size determined by this procedure agrees well with previous estimates $\left(1.7 \times 10^{9}-1.9 \times 10^{9} \mathrm{Da}\right.$, approximately $2550-2850 \mathrm{~kb}$ ) obtained by the renaturation rate method for strains belonging to the corynebacteria group (Bak et al., 1970; Crombach, 1978).

The genomes of B. lactofermentum and C. glutamicum gave well-resolved restriction patterns when digested with endonucleases recognizing AT-rich octanucleotides. The same happens with other bacteria belonging to the 'glutamic acid group', such as Brevibacterium flavum, Brevibacterium ammoniagenes and Corynebacterium callunae; 
the chromosome of $C$. callunae was about $500 \mathrm{~kb}$ smaller than those of the other strains (unpublished observations).

$B$. linens showed a distinct behaviour, perhaps because of its higher $G+C$ content. The sequence ${ }^{5 \prime} \mathrm{T}^{\prime T} T A A A^{3 \prime}$ is rarer than predicted from the $\% \mathrm{G}+\mathrm{C}$ of this strain; assuming a value of 64 for the $\% \mathrm{G}+\mathrm{C}$, the sequence should occur once every $30 \mathrm{~kb}$, with about 100 fragments resulting from digestion with $\mathrm{DraI}$ instead of the eight fragments observed. The ${ }^{5^{\prime}} \mathrm{TTTAAA}^{3^{\prime}}$ sequence is much rarer than the ${ }^{5^{\prime}} \mathrm{CTA} \mathrm{G}^{3^{\prime}}$-containing sequences recognized by $X b a I$ and SpeI. In E. coli and other bacteria it was reported that the oligonucleotide frequency is not only dependent on $\mathrm{G}+\mathrm{C}$ content but it is also strongly biased by codon usage (McClelland et al., 1987; Phillips et al., 1987). It is likely that the same occurs in B. linens, although due to the small extent of the chromosome of $B$. linens that has been sequenced it is not possible to confirm this possibility.

Some authors (Forbes et al., 1991; Grothues \& Tümmler, 1991) have claimed that restriction fragment fingerprinting is useful for studying genetic relatedness of different strain isolates, but results with other species such as Helicobacter pylori (Taylor et al., 1992) and Bacillus cereus (Carlson et al., 1992), and also our own results, prove that, at least for groups of very heterogeneous bacteria, the criteria of grouping according to restriction fragment patterns has little taxonomic value. The two $B$. lactofermentum strains (and to a lesser degree the $C$. glutamicum strain) are very closely related from the point of view of biochemical and morphological characteristics, but they represent a heterogeneous family of isolates with different genome structures. Whether this diversity results from deep chromosome rearrangements will only be clarified by fine mapping and determination of relative gene positions on the genome of these strains.

This technique is, however, useful to establish the degree of relatedness among different strains of the same species. As shown in Fig. 4, closely related strains retain very similar restriction patterns, which are different from the restriction patterns of other soil isolates of the same species.

\section{ACKNOWLEDGEMENTS}

This work was supported by grants of the BRIDGE Program of the CE, Brussels (BIOT CT91-0264RZJE) and the CICY'T, Madrid (BIO708-92). A. Correia was supported by a fellowship of the Science Program of JNCIT, Lisbon. We thank K. Roy for critical reading of the manuscript, W. Liebl for sending the strain DSM 20412, Juan Traver (Millipore Ibérica) for technical help with the Biolmage analyser, and M. I. Corrales, M. A. Santos and R. Barrientos for excellent technical assistance.

\section{REFERENCES}

Bak, A. L., Christiansen, L. \& Staudrup, A. (1970). Bacterial genome sizes determined by DNA renaturation studies. J Gen Microbiol 64, 377-380.

Bourgeois, P. L., Mata, M. \& Ritzenthaler, P. (1989). Genome comparison of Lactococcus strains by pulsed-field gel electrophoresis. FEMS Microbiol Lett 59, 65-70.
Carlson, C. R., Grønstad, A. \& Kolst, A.-B. (1992). Physical maps of the genomes of three Bacillus cereus strains. J Bacteriol 174, 3750-3756.

Crombach, W. H. J. (1978). DNA base ratios and DNA hybridization studies of coryneform bacteria, mycobacteria and nocardiae. In Coryneform Bacteria, pp. 161-179. Edited by I. J. Bousfield \& A. G. Callely. London: Academic Press.

Daniel, P., De Waele, E. \& Hallet, J.-H. (1993). Optimisation of transverse alternating field electrophoresis for strain identification of Leuconostoc oenos. Appl Microbiol Biotechnol 38, 638-641.

Eikmanns, B. J., Kircher, M. \& Reinscheid, D. J. (1991). Discrimination of Corynbacterium glutamicum, Brevibacterium flavum and Brevibacterium lactofermentum by restriction pattern analysis of DNA adjacent to the hom gene. FEMS Microbiol Lett 82, 203-208.

El-Adhami, W., Roberts, L., Vickery, A., Inglis, B., Gibbs, A. \& Stewart, P. R. (1991). Epidemiological analysis of a methicillinresistant Staphylococcus aureus outbreak using restriction fragment length polymorphisms of genomic DNA. J Gen Microbiol 137, 2713-2720.

Fiedler, F., Schäffler, M. J. \& Stackebrandt, E. (1981). Biochemical and nucleic acid hybridization studies on Brevibacterium linens and related strains. Arch Microbiol 129, 85-93.

Forbes, K. J., Bruce, K. D., Jordeus, J. Z., Ball, A. \& Pennington, T. H. (1991). Rapid methods in bacterial DNA fingerprinting. J Gen Microbiol 137, 2051-2058.

Grothues, D. \& Tümmler, B. (1991). New approaches in genome analysis by pulsed-field gel electrophoresis: application to the analysis of Pseudomonas species. Mol Microbiol 5, 2763-2776.

Jones, D. \& Collins, M. D. (1986). Irregular non-sporing Grampositive rods. In Bergey's Manual of Systematic Bacteriology, vol. 2, pp. 1261-1264. Edited by S. T. Williams, M. E. Sharpe \& J. Holt. Baltimore: Williams and Wilkins.

Krawiec, S. \& Riley, M. (1990). Organization of the bacterial chromosome. Microbiol Rev 54, 502-539.

Leblond, P., Francou, F.-X., Simonet, J.-M. \& Decaris, B. (1990). Pulsed-field gel electrophoresis analysis of the genome of Streptomyces ambofaciens strains. FEMS Microbiol Lett 72, 79-88.

Liebl, W., Ehrmann, M., Ludwig, W. \& Schleifer, K. H. (1991). Transfer of Brevibacterium divaricatum DSM $20297^{\mathrm{T}}$, Brevibacterium flavum DSM 20411, Brevibacterium lactofermentum DSM 20412 and DSM 1412, and Corynebacterium lilium $^{\mathrm{T}}$ DSM 20137 ${ }^{\mathrm{T}}$ to Corynebacterium glutamicum and their distinction by rRNA gene restriction patterns. Int J Syst Bacteriol 41, 255-260.

Malumbres, M., Gil, J. A. \& Martín, J. F. (1993). Codon preference in corynebacteria. Gene 134, 15-24.

McClelland, M., Jones, R., Patel, Y. \& Nelson, M. (1987). Restriction endonucleases for pulsed-field mapping of bacterial genomes. Nucleic Acids Res 15, 5985-6005.

Martín, J. F. (1989). Molecular genetics of amino acid-producing corynebacteria. In Microbial Products: New Approaches, pp. 25-59. Edited by S. Baumberg, I. Hunter \& M. Rhodes. London: Cambridge University Press.

Martín, J. F., Santamaría, R. I., Sandoval, H., Del Real, G., Mateos, L. M., Gil, J. A. \& Aguilar, A. (1987). Cloning systems in amino acidproducing corynebacteria. Bio Technology 5, 137-146.

Phillips, G. J., Arnold, J. \& Ivarie, R. (1987). The effect of codon usage on the oligonucleotide composition of the E. coli genome and identification of over- and under-represented sequences by Markov chain analysis. Nucleic Acids Res 15, 2627-2638.

Smith, C. L., Econome, J. G., Schutt, A., KIco, S. \& Cantor, C. R. (1987). A physical map of the Eschericbia coli K12 genome. Science 236, 1448-1453. 
Sobral, B. W. S., Honeycut, R. J. \& Atherly, A. G. (1991). The genome of the family Rhizobiaceae: size, stability and rarely cutting restriction endonucleases. J Bacteriol 173, 704-709.

Suzuki, K. \& Komagata, K. (1983). Taxonomic significance of cellular fatty acid composition in some coryneform bacteria. Int $J$ Syst Bacteriol 33, 188-200.

Tanskanen, E. I., Tulloch, D. L., Hillier, A. J. \& Davidson, B. E. (1990). Pulsed-field gel electrophoresis of $S \mathrm{maI}$ digests of lacto- coccal genomic DNA, a novel method of strain identification. Appl Environ Microbiol 56, 3105-3111.

Taylor, D. E., Eaton, M., Chang, N. \& Salama, S. M. (1992).

Construction of a Helicobacter pylori genome map and demonstration of diversity at the genome level. J Bacteriol 174, 6800-6806.

Received 16 May 1994; accepted 25 May 1994. 